Journal of American Studies, 55 (202 I), I, 48-74

(C) Cambridge University Press and British Association for American Studies 2019. This is an Open Access article, distributed under the terms of the Creative Commons Attribution licence (http://creativecommons.org/licenses/by/4.0/), which permits unrestricted re-use, distribution, and reproduction in any medium, provided the original work is properly cited.

doi:10.1017/S0021875819000033 First published online 14 May 2019

\title{
Casting a Black Gandhi: Martin Luther King Jr., American Pacifists and the Global Dynamics of Race
}

\author{
JAKE HODDER 두
}

Martin Luther King Jr. is widely read through his association with Gandhi's ideas and practice. Whilst it is important to neither overstate nor ignore this influence, the paper retraces the work undertaken behind the scenes to script this relationship for wider audiences. It questions how King's casting as America's black Gandhi was strategically undertaken, by whom and for what purposes, as well as exploring why it was ultimately short-lived. Although King experimented with Gandhism briefly in the late 1950s, by the early 1960s the idea had largely been dropped. In particular, the paper focusses on the role played by the American pacifist movement up to, and including, organizing King's visit to India in 1959. These sources are used to make a broader argument that King's ability to inhabit Gandhi's legacy during the movement's early years was critical to forging global anticolonial connections. As such the paper argues that nonviolence was more than a repertoire of resistance techniques, but a spatial mechanism which could fold scale, bridge distance, and thereby produce and reshape racial solidarity itself.

On I I February I 959, just after arriving in India, Martin Luther King Jr. and his wife Coretta awoke early to lay down a wreath on the shrine of the Raj Ghat in Delhi, the memorial site where Gandhi's body had been cremated. ${ }^{\text {I }}$ It was a fitting tribute paid by a man whose recent, meteoric rise to fame could be partly credited to his outspoken commitment to Gandhi's philosophy of nonviolence. When King was questioned in 1957 on the books which most influenced his work, for example, besides Thoreau's Essay on Civil Disobedience and Rauschenbusch's Christianity and the Social Crisis, he listed three Gandhian classics: Louis Fischer's landmark biography, Gandhi's own autobiography and Richard Gregg's The Power of Nonviolence. ${ }^{2}$

School of Geography, University of Nottingham. Email: jake.hodder@nottingham.ac.uk.

' Coretta Scott King, My Life with Martin Luther King, Jr. (New York: Rinehart and Winston, 1969), 100-1.

${ }^{2}$ Louis Fischer, The Life of Mahatma Gandhi (New York: Harper \& Brothers, 1950); Mohandas Gandhi, Gandhi's Autobiography: The Story of My Experiments with Truth (New York: Public Affairs Press, 1948); Richard Gregg, The Power of Non-violence (London: George Routledge \& Sons, 1936). Letter from King to Lawrence M. Byrd, 25 April 1957, in Clayborne Carson, Susan Carson, Adrienne Clay, Virginia Shadron and 
Although he never met Gandhi (he was nineteen when the Indian leader was assassinated in January I 948), King's mentors during his student years, initially at Atlanta's Morehouse College, and later at Crozer Theological Seminary and Boston University, impressed upon him the significance of Gandhi's work. At Morehouse, King was introduced to Gandhi by then college president Benjamin Mays; as a seminarian, he was inspired when he heard Mordacai Johnson, president of Howard University, speaking of his recent visit to India; and as a doctoral student in Boston he was greatly influenced by the theologian Howard Thurman, who, along with Mays, had firsthand experience of meeting Gandhi in $1936 .{ }^{3}$ King draws out these connections in "Pilgrimage to Nonviolence," the sixth chapter of his best-selling book on the Montgomery bus boycott, Stride toward Freedom. ${ }^{4}$ More than any other source, this text was instrumental in narrating King's intellectual journey to Gandhi. Whilst previously he had some appreciation of nonviolence as an individual practice, King wrote, it was through Gandhi that he came to understand how the "love ethic of Jesus" could be mobilized into "a powerful and effective social force on a large scale."s

Kieran Taylor, eds., The Papers of Martin Luther King, Jr., Volume IV, Symbol of the Movement January 1957-December 1958 (Berkley: University of California Press, 2000), I 83-84. Fischer's biography forms the basis of Richard Attenborough's Academy awardwinning 1982 film Gandhi. For the significance of Richard Gregg's work see Joseph Kosek, "Richard Gregg, Mohandas Gandhi, and the Strategy of Nonviolence," Journal of American History, 91, 4 (2005), I 3 1 8-48. Gandhi-King comparisons are ubiquitous in academic and popular literature alike; useful starting points include Michael Nojeim, Gandhi and King: The Power of Nonviolent Resistance (Westport, CT: Praeger, 2004); Bidyut Chakrabarty, Confluence of Thought: Mohandas Karamchand Gandhi and Martin Luther King, Jr. (Oxford: Oxford University Press, 2013); and Mary King, Mahatma Gandhi and Martin Luther King, Jr.: The Power of Nonviolent Action (Paris: UNESCO Publishing, 1993).

${ }^{3}$ Quinton Dixie and Peter Eisenstadt, Visions of a Better World: Howard Thurman's Pilgrimage to India and the Origins of African American Nonviolence (Boston, MA: Beacon Press, 20II). Although Gandhi never visited the USA, he spoke and corresponded with many Americans. An account of these exchanges can be found in Leonard A. Gordon, "Mahatma Gandhi's Dialogues with Americans," Economic and Political Weekly, 37, 4 (2002), 337-52; Charles Chatfield, The Americanization of Gandhi (New York: Garland, 1976); and Sean Scalmer, Gandhi in the West: The Mahatma and the Rise of Radical Protest (Cambridge: Cambridge University Press, 20 I I). In relation to African Americans specifically see Sudarshan Kapur, Raising Up a Prophet: The African-American Encounter with Gandhi (Boston, MA: Beacon Press, 1992); Sean Chabot, Transnational Roots of the Civil Rights Movement: African American Explorations of the Gandhian Repertoire (Plymouth: Lexington Books, 2011); and Nico Slate, Colored Cosmopolitanism: The Shared Struggle for Freedom in the United States and India (Cambridge, MA: Harvard University Press, 2012).

${ }^{4}$ Martin L. King, Stride toward Freedom: The Montgomery Story (New York: Harper and Row, 1958).

s Ibid., 78-79. 
Many historians have been rightly suspicious of this account. For one, the "pilgrimage" chapter sits awkwardly apart from the rest of the text; unlike the rest of the book, King consulted heavily with advisers over how best to write the chapter, gathering extensive comments, revisions and additions, as well as reproducing the work of others without acknowledgement. King's Pulitzer Prize-winning biographer, David Garrow, has written of the chapter that it is "a poorly organized and at times erroneous hodgepodge of contributions from a number of King's editorial advisors." ${ }^{6}$ It was written hastily alongside other commitments in the late 1950 s and reflects the vulnerability of both the movement and King's leadership in its early years.

Instead, biographers have questioned King's familiarity with, or depth of commitment to, Gandhi's teachings by demonstrating the often eclectic way he drew from them. ${ }^{7}$ The Gandhi which King came to know had been carefully screened through the black Christianity of his early teachers and the moral lens of his American Gandhian advisers. The translation of Gandhi into American culture was a selective process which sectioned off the readily transferable message of nonviolence and civil disobedience from what was perceived as Gandhi's more exotic and culturally contingent eccentricities. ${ }^{8}$ Accordingly, as Keith Miller has argued, King paid virtually no attention to the "communal Gandhi, the cloth-spinning Gandhi, the vegetarian Gandhi, the ascetic Gandhi, the celibate Gandhi, the Hindu Gandhi, and the fastunto-death Gandhi." In fact, King rarely engaged with many of the basic religious values and practices which Gandhi himself viewed as most important.9

The timeline of King's Gandhian turn has also been subject to debate. Many firsthand sources suggest that King's initial knowledge of Gandhi was limited, and that the move toward a formal adoption of nonviolence evolved more speculatively during the course of the campaign. King's colleague in the Montgomery Improvement Association (MIA) and early biographer, Lawrence D. Reddick, noted that when King debuted in Montgomery, "he did not mention Gandhi or anything directly relating to the Mahatma's theory or practice of social change." ${ }^{\circ}$ Likewise, close King adviser and

${ }^{6}$ David J. Garrow, Bearing the Cross: Martin Luther King Jr., and the Southern Christian Leadership Conference (New York: W. Morrow, I986), i I I.

7 King's biographers to make this case include David L. Lewis, King: A Critical Biography (New York: Praeger, 1970); Garrow; and Peter Ling, Martin Luther King, Jr. (London: Routledge, 2002).

${ }^{8}$ See Chatfield; Jake Hodder, "Conferencing the International at the World Pacifist Meeting, I 949," Political Geography, 49 (Nov. 20 I 5), 40-50.

9 Keith D. Miller, Voice of Deliverance: The Language of Martin Luther King, Jr. and Its Sources (Athens: University of Georgia Press, 1998), 98.

${ }^{10}$ Lawrence D. Reddick, Crusader without Violence: A Biography of Martin Luther King Jr. (New York: Harper, 1959), 133. 
pacifist Bayard Rustin noted promisingly in a report written three months after the start of the boycott that the young leader was gradually "developing a decidedly Gandhi-like view." Rustin noted in an interview some years later that at the outset of the boycott King had no sustained philosophical or moral commitment to nonviolence, even if he had been exposed to pacifism and Gandhi previously. ${ }^{\text {I }}$

Finally, King's turn to Gandhi was also short-lived. Many sources suggest that King experimented with Gandhism briefly in the late i950s, but that by the early i 960 s the idea had largely been dropped in favour of a more dressed-down form of "nonviolent direct action." Whereas King's earlier formulation of nonviolence was a like-for-like espousal of Gandhi's moral and spiritual case, as his career developed these elements fell away. ${ }^{12}$ Speaking on Face the Nation, in sermons such as his famous Riverside Address, and in popular magazines such as Look or Ebony, King continued to passionately make a case for nonviolence until the very end of his life, but in starkly strategic terms with Gandhi notably absent from the frame. ${ }^{13}$

The issue of when, specifically, King became aware of Gandhi or retreated from him may seem peculiarly narrow questions to many. Recent scholarship has tended to emphasize that the African American and Indian encounter took place over a longer period and was shaped by issues of anticolonialism and caste as much as by Gandhi. ${ }^{14}$ Likewise, others have stressed that King's nonviolent approach was not an importation, but rooted in an African American political tradition. ${ }^{\text {Is }}$ Yet whilst it is important to neither overstate nor ignore the intellectual impact of Gandhi on King, irrespective

${ }^{11}$ Bayard Rustin, Report on Montgomery, Alabama (New York: War Resisters' League, 2 I March 1956); Bayard Rustin interview with August Meier and Elliott Rudwick, 28 March 1974, Box 58, August Meier Papers, Sc MG 340, Schomburg Center for Research in Black Culture, New York Public Library (hereafter AM).

${ }^{12}$ For example, see Martin Luther King Jr., "Nonviolence and Racial Justice," Christian Century, 6 Feb. 1957.

13 Transcript of Face the Nation interview broadcast over the CBS Television Network and CBS Radio Network 29 Aug. 1965, the King Center, Atlanta, Georgia, at www.thekingcenter. org/archive/document/face-nation-interview, accessed i I Sept. 2 108; Martin Luther King Jr., "Beyond Vietnam," in Clayborne Carson and Kris Shepard, eds., A Call to Conscience: The Landmark Speeches of Dr. Martin Luther King, Jr. (New York: Grand Central Publishing, 200I), I 33-64; King, "Showdown for Non-violence," Look, I 6 April 1968, 23-25; and King, "Nonviolence: The Only Road to Freedom," Ebony, 4 May 1966, 28-34.

${ }^{14}$ For example, Kapur, Raising Up a Prophet; Slate, Colored Cosmopolitanism; Gerald Horne, The End of Empires: African Americans and India (Philadelphia: Temple University Press, 2008); Daniel Immerwahr, "Caste or Colony? Indianizing Race in the United States," Modern Intellectual History, 42 (2007), 275-301.

is For example, Greg Moses, Revolution of Conscience: Martin Luther King Jr. and the Philosophy of Nonviolence (New York: Guildford Press, 1997). 
of this, King's ability to inhabit Gandhi's legacy was crucial to embedding and sustaining his influence in the early movement. As Nico Slate has argued, it enhanced his appeal to black audiences who saw it representing courage, resistance and the rising coloured world, and yet simultaneously was centred on a form of nonviolent protest which was less threatening to white audiences. ${ }^{16}$ Behind the scenes, considerable work was done to script this association and cast King in the role of America's black Gandhi, which shaped both the movement in the US and, crucially, as I explore below, its wider international reach. The story of how King became Gandhian - or, more accurately, came to be seen as Gandhian - is therefore of greater significance than it may initially seem.

This paper questions how King's path to Gandhi was carefully and strategically plotted, by whom, and for what purposes, as well as interrogating, ultimately, why it was short-lived. Although there are several possible answers to these questions, I turn specifically to the role played by the American pacifist movement, which had more to gain than most in emphasizing King's Gandhian credentials. In particular, I draw on the archives of the American Friends Service Committee, the Fellowship of Reconciliation, and the War Resisters League, archetypes of what civil rights historian Aldon Morris has termed "movement half-way houses," which connected emerging black activists with older protest traditions. ${ }^{17}$ I start by outlining the longer role played by pacifists in experimenting with Gandhian methods against racial segregation in the United States from the early 1940s, before showing how, in Montgomery and in the years which followed, pacifists played an integral part in moulding the public perception of King. They used a range of means in order to do so: journals and magazines, comic books and film, and most significantly they organized and part-funded the Kings to visit India itself in 1959. The paper uses private correspondence in relation to King's visit to critically examine the political work done in staging the trip.

I employ these sources to make a broader argument: that King's association with Gandhi was crucial to placing him within a diasporic and, at times, global conversation. ${ }^{18}$ Contrary to reading the Gandhian King through the lens of

${ }^{16}$ Slate.

${ }_{17}$ Aldon D. Morris, The Origins of the Civil Rights Movement: Black Communities Organizing for Change (London: Collier Macmillan, 1984).

${ }_{18}$ Situating the civil rights movement within an international context has been a dominant feature of recent scholarship. For example, Thomas Borstelmann, The Cold War and the Color Line: American Race Relations in the Global Arena (Cambridge, MA: Harvard University Press, 200I); Mary L. Dudziak, Cold War Civil Rights: Race and the Image of American Democracy (Princeton, NJ: Princeton University Press, 2000); Brenda G. Plummer, In Search of Power: African Americans in the Era of Decolonization, 19561974 (Cambridge: Cambridge University Press, 2013); Jonathan Rosenberg, How Far 
South Asia alone - or what leading peace scholar Johan Galtung called the "curious circulation of waves of nonviolence between India and the United States" - I suggest that what Gandhi offered in practice was a means to build connections and solidarities across the wider Afro-Asiatic world. ${ }^{19}$ As Vijay Prasad has noted, from the I 920 s onwards the success of Indian anticolonialism, which became increasingly synonymous with Gandhi, led to calls for a "black Gandhi" among many groups faced with racial or colonial oppression. ${ }^{20}$ The story of King's engagement with Gandhi must, therefore, be read in the context of a wider "Gandhian moment" - a period in which racial struggles of various stripes sought to explicitly align themselves with the late Mahatma's legacy. ${ }^{21}$ In casting King in the role of a black Gandhi, American pacifists sought not only to embed nonviolence into the emerging civil rights movement, but, of equal importance, to embed the civil rights movement within an emerging global history of nonviolence, contemporaneously taking root elsewhere in places such as Ghana, Nigeria and South Africa. Yet by the mid-1960s the name Gandhi, once practically shorthand for anticolonial pan-Africanism, became increasingly unpopular as the political mood shifted across the continent. The paper shows how King's own Gandhian positioning needs to read within this broader context; a story of the rapidly diminishing currency which Gandhi offered on the world stage.

This perspective offers fresh insights to the ways we understand the nature of nonviolence itself and the role that it played in the civil rights movement and beyond. Whilst commonly interpreted in narrowly technical or moral terms (i.e. the ethics and practice of a repertoire of resistance techniques: strikes, boycotts, civil disobedience), I argue that Gandhian nonviolence also worked as a spatial mechanism - able to bend and fold scales, bridge political and geographical distance, and thereby produce and reshape racial solidarity itself. Casting King in the role of a black Gandhi was a key element in enabling his transformation from a young, dynamic leader of a community boycott of local bus services into a global champion of racial justice, pulling together Montgomery with waves of anticolonialism from Johannesburg to Accra and Delhi.

from the Promised Land? World Affairs and the American Civil Rights Movement from the First World War to Vietnam (Princeton, NJ: Princeton University Press, 2006).

19 Johan Galtung, "Conflicts and Realities: Reflections on Non-violence," Our Generation against Nuclear War, 3, I (1964), 26-33, 26.

${ }^{20}$ Vijay Prasad, "Black Gandhi," Social Scientist, 37, I-2 (2009), 3-20.

${ }^{21}$ For the global reach of Gandhi's legacy see David Hardiman, Gandhi: In His Time and Ours (New York: Columbia University Press, 2003); Debjani Ganguly and John Docker, eds., Rethinking Gandhi and Nonviolent Relationality: Global Perspectives (London: Routledge, 2008). 


\section{Jake Hodder}

Glenn Smiley, a field secretary for the leading American pacifist group the Fellowship of Reconciliation (FOR), had never met Martin Luther King Jr. before arriving in Montgomery in February 1956. Three months had passed since the start of the Montgomery bus boycott, and Smiley had been sent to work alongside the movement's leaders, distribute literature and discuss the importance of Gandhi and nonviolence. ${ }^{22}$ Smiley had been introduced to King by another pacifist, the African American head of the War Resisters' League (WRL), Bayard Rustin, who himself had arrived in Montgomery a month earlier to act as a tactical adviser. ${ }^{23}$ Rustin had spent twelve years as a field secretary for the FOR, during which time he had written and lectured on the possibilities of using nonviolence to tackle racial segregation in the US, including drawing on his firsthand experiences meeting Gandhian leaders in India and West Africa. ${ }^{24}$ In the months which followed Smiley and Rustin separately tutored King in the philosophical and practical tenets of Gandhian nonviolence. Up to that point the bus boycott had largely developed in an impromptu fashion, predominately organized by the city's African American women with little outside consultation or support. ${ }^{25}$ Secretary of the MIA Robert Graetz later reflected that although "non-retaliation" had been a guiding belief of the movement from the outset, "most of the credit for giving form and substance to this principle must go to Glenn Smiley." ${ }^{2} 6$ Shortly after arriving Smiley wrote back to the FOR that he had a good "in" with King, who had "some interest" in Gandhian ideas, but in terms of the wider perception of Montgomery, the "story is not a clear one ... not nearly as clear as we would like." Smiley believed that if King could "really be won to a faith in non-violence there is no end to what he can do ... who knows? Maybe King will latch on to something big here yet." ${ }^{27}$

Pacifist groups were some of the first outsiders to recognize the significance of what was taking place in Montgomery. This reflected the pioneering work which they had undertaken for at least a decade before Rosa Parks refused to

${ }^{22}$ For example, memorandum by Smiley, 7 April 1956, Series E, Box 16, in the Fellowship of Reconciliation Records (DG o I3), Swarthmore College Peace Collection (hereafter FOR).

${ }^{23}$ Rustin arrived at the behest of A. Philip Randolph; accounts of his work in Montgomery are detailed by several of his biographers, for example Jervis Anderson, Bayard Rustin: Troubles I've Seen (New York: HarperCollins, I 997); and John D'Emilio, Lost Prophet: The Life and Times of Bayard Rustin (New York: Simon and Schuster, 2003).

${ }^{24}$ Jake Hodder, "Toward a Geography of Black Internationalism: Bayard Rustin, Nonviolence, and the Promise of Africa," Annals of the American Association of Geographers, 106, 6 (2016), 1360-77.

${ }^{25}$ For example, Jo Ann Gibson Robinson, The Montgomery Bus Boycott and the Women Who Started It: The Memoir of Jo Ann Gibson Robinson (Knoxville: University of Tennessee Press, 1989).

${ }^{26}$ Rev. Robert Graetz to Alfred Hassler, is May i 957, Series E, Box I6, FOR.

27 Smiley to Al Hassler and John Swomley, 29 Feb. 1956, Series E, Box 17, FOR. 
give up her bus seat. In 1942 James Farmer, then FOR field secretary and later to become a civil rights leader, argued that pacifists needed to redefine their ideology in ways specifically conversant with tackling racism, capitalizing on what he termed "the race logic of pacifism." ${ }^{28}$ Farmer and co-secretary Rustin independently made the case that few were better equipped than pacifists (spiritually, ideologically and practically) to mobilize Americans in a comprehensive, nonviolent campaign to abolish racial discrimination. ${ }^{29}$ Rustin and Farmer were part of a small, young and committed band of radical pacifists drawn to the FOR after the appointment of one-time union organizer A. J. Muste to head the organization in $1940.3^{30}$ The same year, a "non-violent action committee" was established to study the applicability of Gandhi's approach, marking the group's emerging role as the most important channel for popularizing nonviolence in the US. ${ }^{31}$

The large nonviolent movement envisaged by the FOR and others, however, ultimately required the mass mobilization of black communities who were for the most part beyond pacifists' reach. ${ }^{32}$ This was a realistic appraisal of their own capacity as a group "not itself equipped, organizationally or otherwise, to create a mass movement alone." 33 Hopes of building a Gandhian-inspired movement against racial segregation therefore became reliant on finding a black, Gandhian figure who could lead it. Early promise came in the labour organizer and civil rights leader A. Philip Randolph, whose influential March on Washington Movement (MOWM) in the early I 940 os had earnt him the name the "American Gandhi." Randolph had been drawn to Gandhi's work during his early days with the Brotherhood of Sleeping Car Porters. He later reflected that the Christian beliefs of his father, a minister of the African Methodist-Episcopal Church, tightly aligned with the

${ }^{28}$ James Farmer, "The Race Logic of Pacifism," Fellowship, Feb. 1942, 24-25.

29 Ibid.; Bayard Rustin, "The Negro and Nonviolence," Fellowship, Oct. 1942, I 6.

${ }^{30}$ In 1939 Time magazine named Muste "the Number One U.S. Pacifist." See Leilah Danielson, American Gandhi: A. J. Muste and the History of Radicalism in the Twentieth Century (Philadelphia: University of Pennsylvania Press, 2014).

${ }^{31}$ For general discussion of wartime pacifism and its radicalization see Lawrence Wittner, Rebels against War: The American Peace Movement, 194I-1960 (New York: Columbia University Press, 1969); James Tracy, Direct Action: Radical Pacifism from the Union Eight to the Chicago Seven (Chicago: The University of Chicago Press, 1996); Scott H. Bennett, Radical Pacifism: The War Resisters League and Gandhian Nonviolence in America, 19I5-1963 (Syracuse, NY: Syracuse University Press, 2003); Marian Mollin, Radical Pacifism in Modern America: Egalitarianism and Protest (Philadelphia: University of Pennsylvania Press, 2013).

${ }^{32}$ Racial and industrial department minutes, I7 Sept. 1946, Section II, Series A-I, Box 4, FOR.

33 Plan for nonviolent campaign against Jim Crow by George Houser, I6 June 1944, Box 9, Folder II, Congress of Racial Equality Records, I94I-1967 (Mss I4), Wisconsin Historical Society, Division of Library, Archives, and Museum Collections, Madison, Wisconsin (hereafter CORE). 
Gandhian approach; "I think that perhaps in my work I was distinguished more for my championing of the philosophy and principles of Gandhism than I was, at times, for trade unionism," he told the Washington Post in 1979. ${ }^{34}$ The MOWM was a landmark opportunity for pacifists - "this action of yours may well prove epoch-making," Muste wrote to Randolph in 1943 - and the FOR offered its full support, seconding both Farmer and Rustin to the project. ${ }^{35}$ Yet work with Randolph reaffirmed the imperfect fit between pacifism and the civil rights struggle. As an explicitly "proNegro" and "pro-war" organization, MOWM found success in challenging segregation in the military through appeals to service and patriotism, as well as developing "a sense of self-reliance on the part of the Negro ... through an organization composed of only Negroes." ${ }^{36}$ Hopes of finding a black Gandhi therefore, an ascetic figure who would challenge the basic ills of Western culture (war chief among them), were quickly dashed. Randolph was a sharp pragmatist and, though influenced by Gandhi's method, his approach was drawn straight from his socialist and trade union background. He saw the strength of racial appeals and used nonviolence expediently, quickly withdrawing direct action once a political compromise had been met.

Early work with Randolph exposed the limited leadership role which pacifists could reasonably command in a major civil rights organization and, in the years which followed, their focus necessarily shifted to facilitating training and education in Gandhian methods behind the scenes. They established an extensive programme of workshops, institutes and summer projects aimed at promoting the effectiveness of nonviolence for racial integration to various black activists and groups, undertaking what George Houser referred to as the "valuable softening up work." 37 As the FOR's race relations co-secretaries in the I940s, Rustin and Houser travelled around the country visiting colleges, universities and churches with the purpose of importing Gandhian methods into local-level civil rights organizing. ${ }^{38}$

${ }^{34}$ Edward A. O’Neill “A. Philip Randolph, Hailed as Giant in Civil Rights Battle," Washington Post, i 8 May 1979, at www.washingtonpost.com/archive/local/1979/05/18/ a-philip-randolph-hailed-as-giant-in-civil-rights-battle/cf68c8bf-4cob-44f8-a4b9bodfba7bb542/?utm_term=.9abe340225ad, accessed io Sept. 2018.

35 Muste to Randolph, I I Jan. I 943, Series A-3, Box I 5, FOR; for examples of FOR's support see Sutherland to Rustin, 28 Aug. 1943, Reel 20, Papers of Bayard Rustin (Frederick, MD: University Publications of America, 1988); Jay Holmes Smith to Muste, 8 July 1943, Series A-3, Box I 5 , FOR.

36 "MOWM not Anti-white," 9 July 1943, Reel 22, Papers of A. Philip Randolph (Bethesda, MD: University Publications of America, 1990).

37 Plan for nonviolent campaign against Jim Crow by Houser, I 6 June 1944.

${ }^{38}$ What are interracial institutes and workshops by the Racial-Industrial department, n.d. [c.1947], Series E, Box 16, FOR; plan for race relations institutes, n.d. [c.1946], ibid.; 
This approach drew its clearest organizational form in the founding of the Congress of Racial Equality (CORE) in 1 942. Although CORE was not conceived of as a pacifist organization in the strictest sense, as the FOR's archive reveals, "in practically every instance it is the F.O.R. members in a locality who have taken the initiative in forming the CORE groups and in carrying forward the CORE work." 39 FOR provided much of the group's early funding, including housing the organization for almost eight years, seconding staff time to work on CORE assignments, and jointly sponsoring national projects. Pacifists served as "its nucleus, its moving force," and shaped an unapologetically Gandhian approach through much of its first decade..$^{\circ}$ They specialized in small-scale desegregation projects ranging from lunch counters, theatres and swimming pools to a segregated high-school bowling club in Illinois or unfair employment practices at a chain of ice cream stands in Nebraska. All of these were disseminated through the organization's mouthpiece, CORElator (launched in 1944), which served as a training device in its own right. ${ }^{4 \mathrm{I}}$ CORE ran a number of nationally significant projects in these years, most notably an early prototype of the group's more famous "freedom rides" called the "Journey of Reconciliation" in 1947 in conjunction with FOR. ${ }^{42}$

Through this work, pacifists helped move department stores, restaurants and public transport to the front line of the civil rights struggle and, as Bayard Rustin later reflected, "unconsciously" set in motion an attitude of black protest which was a primer for when opportunities opened under King some years later. ${ }^{43}$ When the Montgomery bus boycott began at the start of December 1955, therefore, pacifist groups were some of the first to

proposed institutes on nonviolent action as applied to race relationships, 30 April I943, Series A-4, Box 2, FOR; also see plan for institute and workshop, n.d. [c.1945], ibid.

39 CORE and relation to FOR, 2 I July i 944, Section II, Series A-4, Box 2, FOR.

${ }^{40}$ Provisional plans for brotherhood mobilization by James Farmer, I 9 Feb. 1942, Section II, Series A-4, Box 2, FOR; John Swomley, "F.O.R.'s Early Efforts for Racial Equality," Fellowship, July-Aug. 1999.

${ }^{41}$ Examples here are found in CORE-lator issues, Oct. 1949; May 1949; Jan. I 95 I and Jan. 1954. CORE's approach, starting with investigation, through to negotiation, public pressure and education, demonstration, and eventually noncooperation, foreshadowed King's own account of how nonviolence works some twenty years later, in Martin Luther King Jr., Why We Can't Wait (New York: Harper \& Row, 1964).

${ }^{42}$ Derek Catsam, Freedom's Main Line: The Journey of Reconciliation and the Freedom Rides (Lexington: University Press of Kentucky, 2009); Marian Mollin, "The Limits of Egalitarianism: Radical Pacifism, Civil Rights, and the Journey of Reconciliation," Radical History Review, 88, I (2004), I I 2-38; Bayard Rustin, "We Challenged Jim Crow," in Bayard Rustin, Devon Carbado and Donald Weise, Time on Two Crosses: The Collected Writings of Bayard Rustin (San Francisco, CA: Cleis Press, 2003), I 4-27.

${ }^{43}$ Interview with Bayard Rustin by August Meier and Elliott Rudwick, 28 March 1974, Box 58, AM. 


\section{Jake Hodder}

recognize its significance. When Smiley first arrived in Montgomery he reported back to the FOR that the time of looking "nostalgically at India, saying 'If we had a revolutionary situation, we too could develop leaders and a nonviolent movement" "was over; "a full-scale revolutionary situation exists. And as has been thought, leadership is forthcoming in the person of Rev. Martin Luther King ... their youthful Negro Gandhi."44 Smiley told the FOR National Office, "The Fellowship was born for a time like this!" and that Montgomery offered pacifists the chance to fulfil their historic role. $^{45}$ As the movement in Montgomery developed, King slowly moved toward a formal acceptance of Gandhian nonviolence. In part this was in response to a stream of supportive letters which identified the movement in Gandhian terms, but it also marked the influence of pacifists, such as Smiley and Rustin, on the ground in Montgomery. ${ }^{46}$ The FOR noted, for example, that "Bayard [Rustin] has had a good influence on King, wrote the much quoted speech of last week, and was in on all the strategy." 47 Rustin organized workshops and fund-raising, including the important Institute of Nonviolence and Social Change, which was attended by black leaders from across the South. These events used Montgomery to articulate a clear intellectual and political message centred on the effectiveness of coordinated, mass nonviolence against racial segregation..$^{48}$ Moreover, the increase in favourable Gandhi comparisons in national coverage of the boycott drove outside support. In January I956, for example, Ella Baker, Stanley Levison, Bayard Rustin and representatives from more than twenty-five religious, political and labour groups formed In Friendship, a New York-based fund-raising group which channelled northern financial support to southern civil rights efforts, including the boycott. ${ }^{49}$ As Thomas Jackson notes, Montgomery represented more than a victory for the moral suasion of nonviolence which King, journalists and scholars proclaimed. The bus boycott was an economic battle between the city's predominantly working-class black population and its vastly better financed white elites. The outside support they mobilized by banking on King's

${ }^{44}$ Nonviolence in the South, March 1956, Section II, Series E, Box 16, FOR.

${ }^{45}$ Release of letter from Charles Lawrence Jr. to Dear Friend, 30 April I956, Section II, Series A-4, Box 3, FOR.

${ }^{46}$ See David J. Garrow, Bearing the Cross: Martin Luther King Jr., and the Southern Christian Leadership Conference (New York: W. Morrow, 1986), 66; Lewis, King, 97; Peter Ling, Martin Luther King, Jr. (London: Routledge, 2002), 47.

47 Smiley to Al Hassler and John Swomley, 29 Feb. 1956, Series E, Box 17, FOR.

${ }^{48}$ See Anderson, Bayard Rustin: Troubles I've Seen; D'Emilio, Lost Prophet.

49 For example, Smiley to Heil Bolinger, 29 Feb. 1956, Series E, Box 16, FOR. For discussion on Ella Baker's relationship to King and commitment to nonviolence see Barbara Ransby, Ella Baker and the Black Freedom Movement: A Radical Democratic Vision (Chapel Hill: University of North Carolina Press, 2003), 192-94. 
Gandhian image of nonviolence and virtuousness was critical to the movement's ultimate success..$^{\circ}$

Pacifists played an important role in this positioning of the movement. Through their organizing networks in the South, they sought to place Montgomery at the centre of a southern-wide web of nonviolent resistance. In the years prior to the founding of King's SCLC, they provided muchneeded strategic support to campaigns from Tuscaloosa, Alabama to Orangeburg, South Carolina, which had been inspired by Montgomery's boycotters but lacked technical experience. Between 1955 and 1958 , the FOR ran over forty workshops on nonviolence in the South in order to foster "a cadre of trained leaders" in the black community, who could organize and coordinate their own nonviolent campaigns. ${ }^{5}$ Moreover, in Montgomery there was a growing recognition that the FOR was "the organization that was responsible for many things that we now do in the Montgomery Improvement Association," with King himself noting that Glenn Smiley's "contribution in our overall struggle has been of inestimable value." ${ }_{52}$ King joined the FOR as a member in 1958, supported financial appeals and spoke at some of the group's conferences, recognizing the pacifist movement as an important source of support.53

In these early years pacifists acted as intermediaries between the black community and white audiences, and helped shape the wider public understanding of King. They did this through a wide range of outlets which, despite their diverse forms, shared the common theme of emphasizing the indebtedness of King to Gandhi. The FOR's in-house journal, Fellowship, for example, published an extensive range of articles (including a stand-alone version of King's "Pilgrimage to Nonviolence" chapter ${ }^{54}$ ) which fused historical accounts of the two "prophets" of nonviolence.5s King was also a regular feature in the New Left magazine Liberation, which was launched in 1956, under the editorship of the radical pacifists Bayard Rustin, A. J. Muste and

so Thomas F. Jackson, From Civil Rights to Human Rights: Martin Luther King, Jr., and the Struggle for Economic Justice (Philadelphia: University of Pennsylvania Press, 2013), 62-68.

${ }_{51}$ The FOR and race relations by Smiley, n.d. [1959], Section II, Series A-4, Box 4, FOR.

52 King to Alfred Hassler, I 8 Jan. I957, in Carson et al., The Papers of Martin Luther King, Jr., Volume IV, I I I; see also King to Rustin, I 7 March 1960, Box 37, Folder 3, Papers of Martin Luther King Jr., Howard Gotlieb Archival Research Center, Boston University, Boston, MA.

${ }_{53}$ Morris, The Origins of the Civil Rights Movement, 166.

${ }_{54}$ Martin Luther King Jr., "My Pilgrimage to Nonviolence" Fellowship, Sept. 1958.

55 For example, the May 1956 issue carried a cover image of King speaking to a crowd the night his home was bombed, and included an article based on a half-hour interview he had with Glenn Smiley on 28 February. See "Walk for Freedom," in Clayborne Carson, Stewart Burns, Susan Carson, Dana Powell and Peter Holloran, eds., The Papers of Martin Luther King, Jr., Volume III, Birth of a New Age, December 1955-December 1956 (Berkley, CA: University of California Press, 1997), 277-80. 
Dave Dellinger. ${ }^{56}$ In virtually every issue through the 1950 s, space was devoted to examining the relationship between pacifism, nonviolence and the civil rights movement. King's own articles were published in the magazine, and were peppered with references to Gandhi. ${ }^{57}$

Fellowship and Liberation were important channels for maintaining a dialogue between the civil rights movement and the peace movement, but pacifists used a series of more imaginative means to reach audiences beyond their conventional readership. In 1957 the FOR wrote, produced and distributed Martin Luther King and the Montgomery Story, a comic-book account of the thirteen-month bus boycott. The script was checked and endorsed in advance by King, who keenly welcomed its accessible format, which, as the FOR's director of communications later noted, was "intended to convey to semiliterate persons the story of nonviolence and its effectiveness." The comic was distributed to African American community leaders in southern cities that were showing signs of unrest, and given to newsstand operators who principally served those communities and to students to place on college campuses. It was used in the FOR's workshops alongside the smaller training pamphlet How to Practice Nonviolence written by Smiley. The comic's initial print run of quarter of a million copies easily made it the FOR's largest publishing event, and it appeared serially in the UK's leading pacifist magazine Peace News. ${ }^{58}$ Moreover, the following year the FOR produced $W$ alk to Freedom, a seventeen-minute film of the boycott which was prepared from news clips overlain by a commentary track. Like the comic, it recounted the story of King and the boycotters and, also like the comic, its distribution was carefully targeted in the South. Travelling throughout church communities, it was a well-received primer for nonviolent action, getting a standing ovation when it premiered at a mass meeting of the MIA in the Hutchinson Street Baptist Church in Montgomery.59

Through both organizing work and wider representations of the movement, then, pacifists sought to fuse Gandhi onto King's growing national reputation. Today, many accounts of King are informed by his association with Gandhi,

${ }^{56}$ For discussion of Liberation's significance see Cristina Scatamacchia, "Politics, Liberation, and Intellectual Radicalism," unpublished PhD thesis, University Of Missouri-Columbia, I 990 .

57 For example, Martin Luther King Jr., "Our Struggle," Liberation, April 1956, 3-6; King, "We Are Still Walking," Liberation, Dec. 1956, 6-9; and King, "The Social Organization of Nonviolence," Liberation, Oct. 1959, 5-7.

58 Andrew Aydin, "The Comic Book That Changed the World," unpublished masters' thesis, Georgetown University, 2012; King to Dear Friends, n.d., Section II, Series A-4, Box 4, FOR; Alfred Hassler to Roy Wilkins, 2 Aug. 1957, Series E, Box 19, FOR; Richard Deats to Paul Gravett, 30 April 1997, cited in Aydin, I 44.

59 Robert Canon to Alfred Hassler and Glenn Smiley, 3 Oct. 1956, Series E, Box 19, FOR. 
and some go on to explore the role played by pacifists in shaping it, but rarely is this considered in light of Gandhi's wider deployment across the Afro-Asiatic world. In the remainder of the paper I examine how King's mobilization of Gandhi's legacy was not unique, but drew its very strength from the similarities it shared with various anticolonial leaders abroad. Whereas African leaders had been outwardly supportive of Gandhi's approach during his life, following his death in I948 India's independence movement was often invoked as the paradigmatic anticolonial model and the name Gandhi became virtually shorthand for black political self-determination. ${ }^{60}$

In Ghana, the anticolonial leader Kwame Nkrumah wrote of Gandhi, "We too mourned his death, for he had inspired us deeply with his political thought." "6r Nkrumah's publication of What I Mean by Positive Action in I 949 was a bold commitment to nonviolent change and, the following year, Ghana's Convention People's Party launched its "positive action" campaigns explicitly modelled on the Gandhian approach. ${ }^{62}$ At the time of independence in 1957 Nkrumah observed, "At first I could not understand how Gandhi's philosophy of non-violence could possibly be effective ... After months of studying Gandhi's policy, and watching the effect it had, I began to see that, when backed by a strong political organisation it could be the solution to colonial problems." 63 As one of the first African nations to achieve independence, Ghana was a beacon of anticolonial hope across the continent and took a leading role in shaping the characteristics of independence movements beyond its borders. The following year, for example, Nkrumah hosted the All African Peoples' Conference in Accra with the central aim of collectively formulating "the Gandhian tactics and strategy of the African Nonviolent Revolution." 64

${ }^{60}$ For example, the Gandhian approach was enthusiastically endorsed at the sth Pan-African Congress in Manchester, England in 1945. See George Padmore, Pan-Africanism or Communism (New York: Roy Publishers, 1956), i 55; Padmore also discusses the application of Gandhian techniques to Ghana in The Gold Coast Revolution (London: Dennis Dobson, I953), 175-79.

${ }^{61}$ Kwame Nkrumah, I Speak of Freedom: A Statement of African Ideology (Accra: Praeger, 1961), 2-3.

${ }^{62}$ Kwame Nkrumah, What I Mean by Positive Action (Accra: Ministry of Information and Broadcasting, 1962); Ama Biney, The Political and Social Thought of Kwame Nkrumah (London: Springer, 20I I). For a comparison of Gandhi and Nkrumah see Robert AddoFening, "Gandhi and Nkrumah: A Study of Non-violence and Non-co-operation Campaigns in India and Ghana as an Anti-colonial Strategy," Transactions of the Historical Society of Ghana, I3, I (1972), 65-85.

${ }^{63}$ Kwame Nkrumah, Ghana: The Autobiography of Kwame Nkrumah (New York: Thomas Nelson and Sons, 1957), vii-viii.

${ }^{64}$ Kwame Nkrumah, Revolutionary Path (New York: International Publishers, I 973), I 32. 


\section{Jake Hodder}

In Nigeria, the leading nationalist Nnamdi Azikiwe actively promoted the Gandhian example through his leadership of the National Council of Nigeria and the Cameroons and through his control of the Nigerian press. His chain of newspapers published a multitude of articles which informed readers of Gandhi's work and promoted its adaptation into the Nigerian context. ${ }^{65}$ Diverse groups within the Nigerian nationalist movement drew from various elements of Gandhi's approach. The economic nationalist and writer Mbonu Ojike, known widely as the "Boycott King" and self-titled "Gandhi of Nigeria," developed a campaign, inspired by India's Swadeshi movement, which aimed to promote African cultural and economic products. The radical Zikist movement, founded by young nationalists in 1946, self-consciously adopted obstructionist Gandhian strategies of mass protest, petitions and strikes under the banner of "positive action." And Aminu Kano sought to adapt Gandhi's techniques to northern Nigeria through a programme of land reform, social reform and peasant cooperatives. ${ }^{66}$

As a devout Muslim, Kano was an unlikely candidate to credit his political philosophy to Gandhi, and yet he exemplifies the observation made by the Kenyan independence activist Tom Mboya that Gandhi's influence in Africa traversed traditional lines of politics, race or religion. ${ }^{67}$ Across the continent, African anticolonial activists of all stripes sought to channel and inhabit Gandhi's legacy. Anil Nauriya has shown how figures as diverse as Ivory Coast's Felix Houphouet-Boigny, Algeria's Malek Bennabi, Senegal's Leopold Senghor and Cameroon's Bernard Fonlon identified Gandhi as an inspiration. ${ }^{68}$ In East Africa, leaders like Kenya's Jomo Kenyatta, Tanzania's Rashidi Kawawa and Zambia's Kenneth Kaunda all paid tribute to the Indian leader. ${ }^{69}$ So much so that by the late 1950s Gandhi had

${ }^{65}$ Matthew Robert Redmond, "Zikism and Nigerian adoption of Gandhi's Discourse of Colonial Resistance," unpublished masters' thesis, Okanagan University College, British Columbia, Canada, 2002.

${ }^{66}$ For Ojike see Linus T. Ogbuji, Seeing the World in Black \& White (Trenton, NJ: Africa World Press, 2007); for the Zikist movement see Redmond; and for Kano see Alan Feinstein, African Revolutionary: The Life and Times of Nigeria's Aminu Kano (New York: Crown, 1973).

67 Tom Mboya, [untitled], Africa Quarterly, 2, 2 (July-Sept. 1962), 76.

68 Anil Nauriya, "Gandhi and West Africa: Exploring the Affinities," The Wire, 5 Nov. 2016, at https://thewire.in/history/gandhi-west-africa-exploring-affinitiesGandhi, accessed 10 Sept. 2018.

${ }^{69}$ For tributes paid to Gandhi see Africa Quarterly, 2, 2 (July-Sept. 1962), 73-76; for Gandhian attitudes to African independence see Pyarelal Nayer, "Gandhiji and the African Question," Africa Quarterly, 2, 2 (July-Sept. 1962), 77; and Mohandas Gandhi, "Mahatma Gandhi on Freedom in Africa," Africa Quarterly, I, 2 (July-Sept. 196r). For a thorough overview of Gandhian work on Africa see Anil Nauriya, The African Element in Gandhi (Delhi: National Gandhi Museum \& Gyan Publishing House, 2006). 
become synonymous with anticolonial pan-Africanism. Whilst some associated it with Indian independence, many more noted that Gandhi's approach had itself been born on African soil during his time in South Africa.

In practice this diverse group of African leaders shared few similarities with one another, and even fewer with Gandhi. In as much as they drew from Gandhism at all, like King they did so selectively, adopting the elements which they believed furthered their cause and, more often than not, dispensing of its more spiritual or religious components. Yet irrespective of how authentically Gandhian these figures were or not, that so many anticolonial leaders in Africa chose to openly invoke the late Mahatma's legacy to frame their own political struggles remains a remarkable curiosity. As much as strategies or techniques, therefore, what Gandhi offered was a shared language and framework through which to build pan-African solidarity.

When pacifists cast King in the role of America's black Gandhi, therefore, they hardwired him into these global political currents. Moreover, they did so knowingly. Pacifist groups in the US had been some of the most alert outside observers and commentators on the unusual preeminence which Gandhi and nonviolence held in African anticolonial movements. American pacifists who had spent time campaigning against segregation and racism in the US (e.g. George Houser, Bayard Rustin, Bill Sutherland), travelled to Africa to work alongside leaders including Nkrumah, Azikwe and Kaunda in the 1950 and 1960s, developing many personal friendships. In 1953, Houser established the American Committee on Africa, a leading channel for anticolonial support, and Sutherland went on to work in both the Ghanaian and Tanzanian governments. $7^{\circ}$

Common amongst pacifist representations of King and Montgomery, therefore, was the recourse to fold the movement into this broader "Gandhian moment" - to remind audiences that in "South Africa 60,000 Africans are 'walking to freedom' a la Montgomery." ${ }^{1}$ Reports in Fellowship were shaped by bigger internationalist concerns, emphasizing how the revolution "sweeping through Asia and Africa [had] not overlooked the states of the one-time confederacy," ${ }^{2}$ and that the civil rights struggle was one element

70 Bill Sutherland and Matt Meyer, Guns and Gandhi in Africa: Pan-African Insights on Nonviolence, Armed Struggle and Liberation (Trenton, NJ: Africa World Press, 2000); George Houser, No One Can Stop the Rain (New York: Pilgrim Press, 1989); Hodder, "Toward a Geography of Black Internationalism"; and Jake Hodder, "Waging Peace: Militarising Pacifism in Central Africa and the Problem of Geography, 1962," Transactions of the Institute of British Geographers, 42, I (2017), 29-43.

${ }^{71}$ Release by John Swomley, 20 March 1957, Section II, Series A-4, Box 4, FOR.

72 "The World in Focus," Fellowship, April 1956. 
of "the worldwide revolt of colonial and former colonial peoples." 73 As an advertisement for the journal in 1957 read,

In its articles, FELLOWSHIP has reported on India's struggle for independence under Gandhi, [and] on the travails of racism in South Africa ... A subscription to FELLOWSHIP will spell out for you in greater detail the close interrelationship of such world issues as these with the domestic problem of racial equality. ${ }^{74}$

Through the lens of Gandhi, Fellowship folded the emerging movement in the United States into a broader geographical and racial arena.

This global emphasis was a characteristic feature of pacifist representations of the movement. On the anniversary of the bus boycott in December 1956, for example, Liberation featured a special issue with statements of support from Eleanor Roosevelt, Ralph Bunche, Roy Wilkins and A. Philip Randolph, as well as Z. K. Matthews, the prominent black South African academic, who told readers how reports of Montgomery had reverberated around the world and especially to those flying the "banner of nonviolent resistance" in South Africa and elsewhere. 75 The comic Martin Luther King and the Montgomery Story featured a double-page spread depicting the Indian movement, with King drawn in the pulpit telling a mass meeting how, years before Montgomery, "a country of $300,000,000$ people won its independence by the same methods." " 6 And almost half of the film Walk to Freedom was, as Smiley noted, "devoted to experiences in South Africa and India, and the growing unrest of the world." 77 During the film's seventeen minutes of "live action shots," one advert read, "You will see the empty buses - and the face of courage - in the Cradle of the Confederacy. You will see white settlers hunting the Mau Mau like animals in the brush of Kenya. You will see the Indian masses thronging to hear Mahatma Gandhi." ${ }^{8}$ Such framings helped circumvent attempts to provincialize Montgomery as an issue of states' rights. The ability of the civil rights movement to leverage US foreign-policy concerns for domestic success (as Borstelmann, Dudziak and others have shown) was partly dependent on the discursive lens of Gandhi which pacifists helped establish.79

${ }^{73}$ Freedom, the South and nonviolence, n.d. [1956], Section II, Series A-5, Box 2, FOR.

${ }^{74}$ Fellowship and human rights in America, n.d. [1957], Section II, Series A-5, Box 3, FOR.

75 "Salute to Montgomery," Liberation, Dec. 1956, 4-5.

${ }^{76}$ Alfred Hassler, Martin Luther King and the Montgomery Story (Nyack, NY: Fellowship of Reconciliation, 1957), го.

77 Glenn Smiley to Martin Luther King Jr., 13 April 1956, in Carson et al., The Papers of Martin Luther King, Jr., Volume III, 2 I 3-I 5.

${ }^{78}$ Walk to Freedom advert, n.d. [1956], Series E, Box 19, FOR.

79 Borstelmann, The Cold War and the Color Line; Dudziak, Cold War Civil Rights. 
This lens also enabled King to interact with many outspokenly Gandhian leaders throughout the late I950s and early 1960s. This included King's first trip overseas to attend Ghana's independence celebrations in 1957 at the personal invitation of Nkrumah, and part-organized by the pacifists Bayard Rustin and Bill Sutherland. King's sermon "The Birth of a New Nation," which he gave upon his return, noted the landmark change which Ghanaian independence represented for all groups facing racial injustice. Speaking of Nkrumah's indebtedness to Gandhi, King preached, "it's a beautiful thing, isn't it? That here is a nation that is now free, and it is free without rising up with arms and with ammunition. It is free through nonviolent means." King later sent Nkrumah a copy of Stride toward Freedom as an exposition of his own "philosophical and theological convictions on nonviolence." $8 \circ$

Pacifists continued to play a significant role in facilitating meetings with African leaders. In 1959 they arranged for the Kenyan nationalist Tom Mboya to visit Atlanta and consult with King and fifty other African American leaders on questions of nonviolence and race. ${ }^{81}$ In May 1960 King met with Zambia's Kenneth Kaunda, perhaps the most vocal champion of Gandhi among Africa's new cadre of leaders. Kaunda was in the US at the invitation of Houser and the American Committee on Africa, and, in a joint press conference with King, emphasized the two leaders' shared belief in nonviolence. A few weeks later King welcomed Kaunda to the Ebenezer Baptist Church in Atlanta. ${ }^{82}$ Later that year Nigeria gained independence and, the following month, King flew to Lagos to attend Azikiwe's inauguration. ${ }^{83}$

King's Gandhian credentials offered a critical mechanism for opening a dialogue with these leaders overseas. From the African perspective, it presented King with a shared vocabulary through which to converse with anticolonial leaders which glossed over some of the obvious differences between the nature of the African American struggle in the US and nationalist movements abroad. From the American perspective, it offered King a means to navigate the difficult high waters of Cold War American foreign policy which had

${ }^{80}$ Martin Luther King Jr. to Kwame Nkrumah, 17 April 1959, in Clayborne Carson, Tenisha Armstrong, Susan Carson, Adrienne Clay and Kieran Taylor, eds., The Papers of Martin Luther King, Jr., Volume V, Threshold of a New Decade, January 1959-December 196o (Berkley, CA: University of California Press, 2005), I 85-86; Martin Luther King Jr., "The Birth of a New Nation," sermon delivered at Dexter Avenue Baptist Church, 7 April I957, in Carson et al., The Papers of Martin Luther King, Jr., Volume IV, I 55-67, I 62.

${ }^{81}$ For example, see Roy Finch to WRL members, June 1959, Series A, Box 3, Records of the War Resisters' League, Swarthmore College Peace Collections, Swarthmore, Pennsylvania.

82 Andy DeRoche, "Dreams and Disappointments: Kenneth Kaunda and the United States, 1960-64," Safundi: The Journal of South African and American Studies, 9, 4 (2008), 369-94.

${ }^{83}$ Namdi Azikiwe to Martin Luther King Jr, 26 Oct. 1960, in Carson et al., The Papers of Martin Luther King, Jr., Volume V, 533-34. 
drowned more radical figures like Du Bois or Robeson. Gandhi offered a perceivably neutral framework through which King could criticize the US abroad by distinguishing between the democratic and moral principles of its society and the racist practices which permeated its politics.

More than anything else, it was King's month-long visit to India in 1959 which cemented his growing reputation as one of Gandhi's most promising disciples. ${ }^{84}$ As King's early biographer David Levering Lewis noted, "Although he would again visit foreign countries on several occasions, the Indian trip was a unique spiritual catharsis," 85 or, as King himself noted, "To other countries I may go as a tourist, but to India I come as a pilgrim." ${ }^{86}$ As elsewhere, pacifists played a central role in organizing the trip through the Quaker group the American Friends Service Committee (AFSC) in collaboration with King's close adviser, Bayard Rustin. Together with his wife Coretta and MIA historian Lawrence D. Reddick, the group travelled the length and breadth of India, staying in each place for a couple of nights and taking full advantage of the new possibilities offered by air travel. Throughout their stay they were accompanied by the AFSC's Jim Bristol, director of the Quaker's International Center in Delhi, who had worked exclusively for three months organizing every aspect of their visit. ${ }^{87}$

Bristol devised an ambitious schedule which took in both a number of key political centres and smaller sites historically associated with Gandhi's life and work. ${ }^{88}$ In the large cities King delivered speeches, took press interviews and attended high-profile public meetings. Although many recognized King as a pioneer of nonviolence, few saw him yet as a significant political figure on the international stage. On the first evening, King was invited to dinner by the Indian Prime Minister, Jawaharlal Nehru, before being privately hosted by the first President of India, Rajendra Prasad, and vice president, the philosopher-politician Sarvepalli Radhakrishnan. ${ }^{8}$ Such invitations were a clear

${ }^{84}$ Firsthand accounts of King's India trip can be found in Martin Luther King, Jr. "My Trip to the Land of Gandhi," Ebony, I 4 (July 1959), 84-92; Coretta Scott King, My Life with Martin Luther King, Jr. (New York: Rinehart and Winston, 1969), 173-78; and With the Kings in India: A Souvenir of Dr. Martin Luther King's Visit to India, FebruaryMarch 1959 (New Delhi, India: Gandhi National Memorial Fund, 1959). Some of the best secondary accounts include Garrow, Bearing the Cross, I I 3-15; Jackson, From Civil Rights to Human Rights, 98-102; Lewis, King, 99-105; Slate, Colored Cosmopolitanism, $224-27$.

${ }^{85}$ Lewis, 105.

${ }^{86}$ Account by Lawrence Dunbar Reddick of press conference in New Delhi, 10 Feb. 1959, in Carson et al., The Papers of Martin Luther King, Jr., Volume V, I25-29, I 26.

${ }^{87} \mathrm{Jim}$ Bristol to David Garrow, 29 Dec. 1987, Archives of the American Friends Service Committee, Philadelphia, PA (hereafter AFSC).

${ }^{88}$ Jim Bristol to Corinne Johnson, Io March 1959, Foreign Service, International Centers, AFSC.

${ }^{89}$ King, My life with Martin Luther King, Jr., I $73-78$. 
demonstration of King's increasing international stature. As the editors of Liberation magazine wrote prior to his departure,

Such a journey is inevitably a kind of turning point in the life of a man early thrust into a position of prominence and leadership. He has been a national figure. When he talks with Nehru and walks through Indian villages with Vinoba Bhave this will be news throughout Asia and Africa and inevitably he now becomes in some degree a world figure. ${ }^{90}$

Accounts of the Kings' time in India have tended to be limited and to rely heavily on King's own speeches, sermons and writings, which focus on three recurrent themes. First, India reinforced the moral rightfulness of Gandhi's approach and its universal applicability to oppressed groups in their struggle for justice. This emphasis was not unexpected given that the Gandhian focus had been the predominant justification for King's visit. Bristol organized for the official invitation to be drafted by the Gandhi Memorial Fund, who sent it to King through the Indian ambassador in Washington. ${ }^{91}$ It noted having "watched with sympathy and admiration" the unfolding Montgomery campaign and suggested that visits to places associated with Gandhi's life and work would offer King beneficial insight into his philosophy of nonviolence. ${ }^{22}$ During the visit King met many of the most important people and places associated with the late Mahatma's life - this included Gandhi's contemporaries who were focussed on nonviolent constructive work such as Jayaprakash Narayan, Vinoba Bhave and R. R. Diwakar. ${ }^{93}$ In virtually every speech given abroad King noted how the unique opportunity to study the Gandhian movement firsthand had deepened his understanding of, and conviction in, the nonviolent approach.

Second, King argued that the visit had allowed him to see the global context of the civil rights struggle. Certainly, the visit bolstered his international reputation: unbeknown to him the Montgomery bus boycott had received more publicity in the Indian press than had the 1956 US presidential election, and the announcement that King was to visit India had filled the nation's front pages. Significantly, Bristol's private correspondence offers us an unvarnished account of the scale of King's reputation in India. He noted that King was regarded as a

\footnotetext{
90 “A Good Journey to Martin Luther King, Jr.," Liberation, Feb. 1959.

${ }^{91}$ Jim Bristol to Corinne Johnson, 24 Dec. 1958, Foreign Service, International Centers, AFSC.

92 G. Ramachandran to Martin Luther King Jr, 27 Dec. 1958, Foreign Service, International Centers, AFSC.

${ }^{93}$ Minutes of the Foreign Service Committee, 5 April 1959, Foreign Service, International Centers, AFSC.
} 
champion of the oppressed peoples of the world - in America, Asia and Africa - and never (with the exception of one question on one occasion) thought of as an American. All the questions with which Americans are bombarded were missing in King's case, both in our public meetings and in private conversations. ${ }^{94}$

King himself wrote in his much-quoted piece "My Trip to the Land of Gandhi," "We were looked upon as brothers with the color of our skins as something of an asset ... the strongest bond of fraternity was the common cause of minority and colonial peoples ... to throw off racialism and imperialism."95 Like his visit to Ghana previously, King used his time abroad to reframe the geographical and political scope of the civil rights movement and joined the American Committee on Africa shortly after his return.

Third, King reflected on how India had enhanced his understanding of the issue of class. "In contrast to the poverty stricken," he wrote, "there are Indians who are rich, have luxurious homes, landed estates, fine clothes and show evidence of over-eating. The bourgeoisie - white, black or brown - behaves the same the world over."96 Privately, it was clear that the India trip had broadened King's understanding of socioeconomic inequalities and the limitations of a nonviolent programme for tackling them. Biographer David Garrow has written, "No longer were India and Gandhi simply rhetorical reference points, and no longer would it be possible to presume that Gandhi and his method had eliminated all of India's serious problems."97 India not only raised King's global sense of racial consciousness, therefore, but also visibly marked its limits. It highlighted the need to fix race within a wider critique of the global socioeconomic system, which he did with increasing intensity after his return..$^{8}$ Abroad, King was exposed to the political crosscurrents of the nonalignment movement and, post-India, internationalism became increasingly prominent and politicized in his speeches, which started to plug in to global issues of poverty, aid and disarmament. 99

In short, India affected King deeply. In his own words, he said, "I have an affection for the Indian people unlike that which I have for any other people in

${ }^{94}$ Bristol to Corinne Johnson, i I March I959, Foreign Service, International Centers, AFSC.

95 King, "My Trip to the Land of Gandhi," 85 . So much was this the case that at times he was thought to be of African heritage and was requested by Indians to speak in his native language. See Jim Bristol to Margaret Eaton, 23 April 1959, Foreign Service, International Centers, AFSC.

97 Garrow, Bearing the Cross, i I 4.

${ }^{8}$ There has been a concerted effort in recent years to excavate the more radical dimensions of King's work and thought, especially during the mid- to late 1960 s which is associated with his outspoken criticism of the Vietnam War and poverty. For example, Cornel West, ed., The Radical King (Boston, MA: Beacon Press, 2014).

99 See Jackson, From Civil Rights to Human Rights. 
the world." ${ }_{100}$ Yet, as with King's earlier account in Stride toward Freedom, we should approach his recollections of the India trip with similar caution. It is important to disentangle how India functioned as a site of spiritual pilgrimage or practical learning from how the presentation of King in the "land of Gandhi" enhanced his position domestically and internationally. Every aspect of the Kings' visit was carefully staged and meticulously photographed. So much so that in a series of confidential letters which Bristol wrote back to Quakers in Philadelphia, he noted how, despite moments of vigour and enthusiasm, the Kings had virtually no interest in India. In fact, according to Bristol, King was "almost totally uninterested in sight-seeing, and shopping, and the remarkable art and craft work of India (I would say about 100\% disinterested). Our hosts and Indian friends get so discouraged receiving negative answers to all suggestions." Instead, he had an "almost fanatical interest in snapshots, pictures and newspaper publicity," Bristol wrote. "Many Indians noticed this and even commented on it. Almost before greeting a person or group they were posing for the camera ... You would have to see it to believe it." Divorced from the richly evocative descriptions of his statements and speeches, King and those close to him were acutely aware of the strategic value which a visit to India could play. "This whole trip is being thought of in terms of the return to the U.S.A. and what will make an impact and produces an effect there," Bristol wrote. ${ }^{101}$ When the Kings awoke early to lay a wreath on Gandhi's shrine, for example, they did so surrounded by photographers.

The King in Bristol's correspondence is physically and mentally exhausted, understandably so given the intensity of his schedule even before arriving in India. Notwithstanding the generally immense demands on the young leader's time in the wake of Montgomery, the India visit also came only five months after a failed assassination attempt in which King had been stabbed at a Harlem book signing of Stride toward Freedom, requiring emergency surgery. ${ }^{102}$ Unsurprisingly, therefore, India took its toll, and King spent two days ill in Ahmedabad. ${ }^{103}$ Bristol's ambitious schedule quickly unravelled: the programme was hacked and cut, Mysore was removed entirely and Bangalore was changed to a day of rest.

The confusion and frustration that these last-minute cancellations caused may partly explain the perception, held by Bristol and others, that King was rudely reserved and easily irritated, often choosing to spend time by himself rather than conversing with local hosts when staying in their homes. Bristol

${ }^{100}$ Martin Luther King Jr. to Swami Vishwananda, 19 May 1959, in Carson et al., The Papers of Martin Luther King, Jr., Volume V, 238-39.

${ }^{101}$ Bristol to Dee, 25 Feb. 1959, Foreign Service, International Centers, AFSC; Bristol to Corinne Johnson, Io March 1959, ibid.

${ }^{102}$ Hugh Pearson, When Harlem Nearly Killed King: The 1958 Stabbing of Dr. Martin Luther King, Jr. (New York: Seven Stories Press, 2004). 
never made these criticisms public, keeping them confidential from both the Kings and King's close adviser, Bayard Rustin. But privately he wrote back to the AFSC, "The general public does not know all this, and to them it has been a wonderful thing, I am sure!! Everywhere the reception to the Kings has been tremendous ... Really a TRIUMPHAL TOUR by Gandhi's foremost present-day disciple!" ${ }^{\circ}{ }^{4}$ Bristol's correspondence offers us an important insight, therefore, of the backstage political work which went into scripting King's tour of India. Travel abroad exposed the tensions between King as an individual and King as the symbolic embodiment of a larger movement. Ernst Kantorowicz's classic treatise on medieval political theology, The King's Two Bodies, offers a fitting analogy. Kantorowicz traced how monarchs simultaneously occupied the "body natural," which lived, experienced and died akin to all humans; and the "body politic," a symbolic and spiritual role conferred on and yet outlasting any one individual. Historically this allowed for the continuity of monarchy even when the monarch themselves died. ${ }^{105}$ Like the mediaeval monarch, our own King had "two bodies": one physical, vulnerable to irritations and exhaustions; the other symbolic, which enabled King to be cast as Gandhi's natural heir and successor. Identifying a duplexity in Bristol's private letters is not to doubt the sincerity or intention of King's visit to India, but rather to show the part played by various coalitions and interests who sought to write their own ambitions onto the figure of King - pacifists chief among them.

In her account of the trip, Coretta wrote that "Martin returned from India more devoted than ever to Gandhian ideals of nonviolence and simplicity of living," but if this was true, it was also short-lived. ${ }^{106}$ The India trip was the high-water mark of King's visible engagement with Gandhi. The cracks and inconsistencies of the trip were telling signs of how, despite pacifists' best efforts, King's casting in the role of a black Gandhi was a part he was to play only briefly. As elsewhere, this needs to be read within the wider international context. In March 1960, in the black township of Sharpeville, South Africa, white police killed more than sixty peaceful black protestors and, in January 196I, Patrice Lumumba, the first legally elected Prime Minister of the Democratic Republic of Congo, was killed in a plot orchestrated by Belgium and the United States. ${ }^{107}$ If Gandhian nonviolence had

${ }^{104}$ Bristol to Dee, 25, 24 Feb. 1959, Foreign Service, International Centers, AFSC; Bristol to Corinne Johnson, io March 1959, ibid.; Corinne Johnson to Bristol, 26 March 1959, ibid.

${ }^{105}$ Ernst Kantorowicz, The King's Two Bodies: A Study in Mediaeval Political Theology (Princeton, NJ: Princeton University Press, 1957).

${ }^{106}$ King, My Life with Martin Luther King, Jr., 178.

107 Belgian writer Ludo De Witte has suggested this was the most important assassination of the twentieth century: Ludo De Witte, The Assassination of Lumumba (London: Verso, 2001). 
flourished in the optimism which was characteristic of the early independence years in Africa, then the Sharpeville massacre and Lumumba's assassination tragically marked its limits. Violence was escalating across the continent and the forms of colonialism which remained (in Algeria, in Zimbabwe and elsewhere) were more recalcitrant and more willing to violently defend the status quo. In this new climate even the most outspokenly Gandhian leaders, like Nkrumah or Azikiwe, found that nonviolence was no longer a credible position for a leading African statesman to take. In practice, the transition from anticolonial activist to government official required a compromise of one's nonviolent principles. As Zambia's fervently Gandhian leader Kenneth Kaunda later reflected, Gandhi's approach was ultimately incompatible with modern statehood; a "thoroughgoing pacifism encourages blanket judgments about political regimes, ruling out the marginal moral distinctions that are the raw stuff of statesmanship."

Within this context, what is remarkable is not King's abandonment of Gandhi, but that he remained wedded to nonviolence at all, despite its increasingly unpopular resonance at home and abroad. Unlike many of his international contemporaries whose nonviolent convictions were tested, and ultimately revised, by entering into government, King's commitment to nonviolence (in domestic and foreign policy) pushed him further from US state policy. Like his criticism of the Vietnam War and the Poor People's Campaign, this enduring vow to nonviolence should, no less, be seen as part of the increasingly radical position of King after $1965 .{ }^{109}$

The late I950s was a precarious time in King's leadership with few key successes, yet it was also a decisive period. The casting of King as America's black Gandhi - a role which was so crucial to embedding and sustaining his early influence-was forged in Montgomery and secured in the immediate months and years which followed. It provided an important script to explain how America's civil rights movement configured within a global context of racial and anticolonial unrest. As King stated in his Nobel Lecture:

In one sense the civil rights movement in the United States is a special American phenomenon which must be understood in the light of American history and dealt with in terms of the American situation. But on another and more important level, what is happening in the United States today is a relatively small part of a world

For a discussion of the Sharpeville massacre see Philip H. Frankel, An Ordinary Atrocity: Sharpeville and Its Massacre (New Haven, CT: Yale University Press, 200 I); Tom Lodge, Sharpeville: An Apartheid Massacre and Its Consequences (Oxford: Oxford University Press, 201 I).

${ }^{108}$ Kenneth Kaunda and Colin Morris, Kaunda on Violence (London: HarperCollins Publishers, I980), 60. ro9 West, The Radical King. 


\section{Jake Hodder}

development ... What we are seeing now is a freedom explosion ... All over the world, like a fever, the freedom movement is spreading. ${ }^{110}$

This paper has explored the part which America's pacifist movement played in cultivating this association - the culmination of two decades of work aimed at transforming race relations in the United States and beyond through the promotion of Gandhian nonviolence. It was pacifists like Bayard Rustin and Glenn Smiley who connected King to a longer tradition of searching for the meaning of Gandhi, not only for American audiences, but for the black diaspora more widely. This backstage direction can be gleaned from a letter Bristol wrote to Garrow in 1987, the year in which he won the Pulitzer Prize for his biography of King. "Why is there no mention at all of the American Friends Service Committee which, after all, sponsored the trip?" Bristol asked, "The AFSC did a lot in the U.S. before the Kings departed, and as AFSC staff I knocked myself out for a total of about 3 months, dropping everything else to plan the visit." "I I This point of omission is not simply one of institutional recognition, but gestures to a larger problematic of how we often take for granted that political ideas, techniques and movements have an innate ability to circulate which obscures the labour and agency required to enable movement to happen. ${ }^{12}$ Pacifists, for one, were critical nodes in funding and organizing the circulation of black intellectuals and activists, but they also had much to gain. As Marion Mollin has argued, the I940s and I950s were a difficult time for American pacifists as the boundaries of dissent became stiflingly limited. As I've written elsewhere, there were clear advantages to be gained by pinning the movement to what was emerging as the key moral issue for progressives in the late I940s: the struggle for racial justice. Working for civil rights at home and anticolonialism abroad offered a clarity of purpose for many pacifists as they sought to refashion the ideology of pacifism from an antiwar agenda into a broader struggle against structural forms of violence. ${ }^{113}$

Yet as King's India trip reveals, these connections were often more complex, and strategically astute, than his speeches and sermons gave credit. Peace archives, like those of the AFSC, offer a fresh angle through which to examine the relationship between King's oft-quoted vision of internationalism (a dawning new age of what he called "geographical togetherness") and the

${ }^{10}$ Martin Luther King Jr., "The Quest for Peace and Justice," Nobel Lecture, University of Oslo, i I Dec. i 964.

${ }^{11}$ Bristol to David Garrow, 2 Dec. 1987, Foreign Service 1959, International Centers Administration, AFSC.

${ }^{12}$ See Stefanie Gänger, "Circulation: Reflections on Circularity, Entity, and Liquidity in the Language of Global History," Journal of Global History, I 2, 3 (2017), 303-18.

${ }^{113}$ Mollin, Radical Pacifism in Modern America, 71; Hodder, "Toward a Geography of Black Internationalism," I 360-77. 
actual increased political role which he began to play internationally from the late 1950s. ${ }^{114}$ I have shown how King's Gandhian credentials cannot be disassociated from these concerns - the geographical and political contours of King's "world perspective" were shaped by a Gandhian moment which helped connect the march toward civil rights at home with wider internationalist currents. Recentring these histories allows us to interrogate what gave certain connections resonance but not others, and how solidarity was constructed across movements which in many ways were largely dissimilar. King's casting as a black Gandhi encouraged more than simple recognition of his competency or familiarity with Gandhi's nonviolent approach, but offered a new vocabulary and framework through which to build international connections between the incipient civil rights movement, anticolonial struggles overseas and new postcolonial states.

Gandhi was as emblematic of these black internationalist connections as he was with the idea of nonviolence. King's gradual distancing from Gandhi was not simply a referendum on nonviolence, therefore, but reflects his diminishing belief that African Americans were politically aligned with an oppressed world of colour which would rise together to dismantle white supremacy. In a remarkable article in Ebony magazine in 1966 King makes this case explicitly himself: "This is no time for romantic illusions about freedom and empty philosophical debate," he wrote. "What is needed is a strategy for change, a tactical program which will bring the Negro into the mainstream of American life as quickly as possible. So far, this has only been offered by the nonviolent movement." By the mid-1960s there was no longer any African or Asian nation which, in King's own words, "shows even the potential of leading a revolution of color in any international proportion. Ghana, Zambia, Tanzania and Nigeria are fighting their own battles for survival ... they offer no hope to Angola, Southern Rhodesia and South Africa, and much less to the American Negro." Instead of reaching out, King argued that African Americans needed to "reform the structures of racist imperialism from within," on which, in a curious twist of fortunes, the wider emancipatory hopes of the Afro-Asiatic world now rested. ${ }^{\text {I }}$ is

King's brief role as a black Gandhi therefore offers us a means to examine the global dynamics of race in a period in which America's own power and influence were being consolidated on a worldwide scale. The story of King and the civil rights movement was no less a part of this, albeit often expressed in cautious and critical ways. By the end of his life King's internationalism had shifted from one focussed on the salvational promise of rising African and

${ }^{114}$ For example, Martin Luther King Jr., "Facing the Challenge of a New Age," Phylon Quarterly, I8, I (1957), 25-34. 


\section{Jake Hodder}

Asian nationhood to a more expansive one-world humanism in which the United States would play a leading part. ${ }^{116}$ Focussed on poverty as much as on race, this perspective sought to capitalize on America's global role, rather than question its legitimacy, to make a moral case for using its wealth and power for positive ends - a vividly different sense of American intervention from that of the unfolding Vietnam War which so occupied the latter part of his life.

\section{AUTHOR BIOGRAPHY}

Jake Hodder is Assistant Professor in Historical Geography at the University of Nottingham. This work was supported by the Arts and Humanities Research Council (grant number AH/ Moo8142/r) and the Economic and Social Research Council (grant number ES/Hor 4675). Earlier versions of the essay were presented at the Two Centuries of Peacemaking conference at Newcastle University and at the annual conference of the Royal Geographical Society (with the Institute of British Geographers) in 2016. The author is grateful to both audiences for their feedback. He would also like to thank David Beckingham, Mike Heffernan, Stephen Legg, the anonymous readers and Celeste-Marie Bernier and Bevan Sewell for their careful reading and suggestions for revision.

${ }^{116}$ This shift is evident in King's later writings such as calls for racial and religious diversity in his formulation of the "World House." See Martin Luther King Jr., Where Do We Go from Here: Chaos or Community? (Boston, MA: Beacon Press, 1967). 